Portland State University

PDXScholar

$3-5-2020$

\title{
Life Satisfaction in Division IAA and Division III Football Players
}

Krista Haunani Francisco

Portland State University

Follow this and additional works at: https://pdxscholar.library.pdx.edu/open_access_etds

Part of the Psychology Commons, and the Public Health Commons Let us know how access to this document benefits you.

\section{Recommended Citation}

Francisco, Krista Haunani, "Life Satisfaction in Division IAA and Division III Football Players" (2020). Dissertations and Theses. Paper 5499.

https://doi.org/10.15760/etd.7373

This Thesis is brought to you for free and open access. It has been accepted for inclusion in Dissertations and Theses by an authorized administrator of PDXScholar. Please contact us if we can make this document more accessible: pdxscholar@pdx.edu. 
Life Satisfaction in Division IAA and Division III Football Players

Krista Haunani Francisco

A thesis in partial fulfillment of the requirements for the degree of

Master of Science

in

Health Studies

Thesis Committee:

Bradley Wipfli, Chair

James Wallis

Randy Miller

Portland State University

2020 


\begin{abstract}
Level of life satisfaction is not something of which many sit down and take appraisal. However, levels of life satisfaction, especially low levels of life satisfaction, can have a direct effect on health. Low levels of life satisfaction cause an increase in self-reported stress. Inversely, high levels of stress cause a decrease in life satisfaction. This decrease in life satisfaction is associated with poor mental and physical health outcomes. A majority of student-athlete healthcare is centered around the physical aspects of health, with mental health just recently becoming a concern. It was apparent through the research for this study that life satisfaction scores can be a good indicator and predictor of possible deficits in both. The purpose of this study was to assess and compare the life satisfaction levels of collegiate football players competing at the Division I AA (DI AA) and Division III (DIII) levels. Satisfaction with life scores were compared between the two divisions with the hypothesis that higher perceived stress levels at the Division I AA level lead to lower Satisfaction with Life scores. The secondary hypothesis being that those experiencing lower levels of perceived control would also report lower life satisfaction. Collegiate football players from Linfield College (DIII) and Portland State University (DI AA) institutions we contacted via email and asked to complete a survey via Survey Monkey. In total 46 individuals responded to the survey $(\mathrm{DI} A \mathrm{~A}=22)(\mathrm{DIII}=19)$. Of the 46 total respondents, five failed to indicate the institution with which they are affiliated. The survey consisted of two portions. The first portion was a demographics survey asking about their past and current athletic experiences and exposures. The second was a previously validated Satisfaction with Life Scale (SWLS) (Diener, Emmons, Larsen\&Griffin, 1985). The primary hypothesis was
\end{abstract}


not supported by the data collected, as both programs reported similar SWLS scores (Linfield=22.51, Portland State University=23.74) and both fell into the "slightly satisfied" category of the SWLS satisfaction range. Institutions were combined for the remainder of the analysis. The secondary hypothesis was supported as a statistically significant relationship between perceived control and SWLS was found (Pearson value= .603 , Sig. $(2$-tailed $)=0.00)$. An additional statistically significant relationship between perceived control and average hours of sleep per night was found (Pearson value $=.346$, Sig. $(2$-tailed $)=.025)$ 


\section{Table of Contents}

Abstract....................................................................

List of

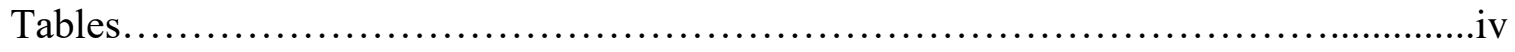

List of

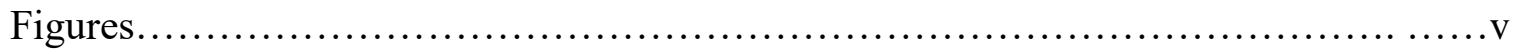

\section{Chapter 1}

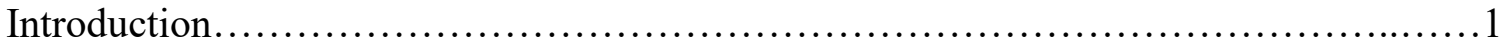

Chapter 2

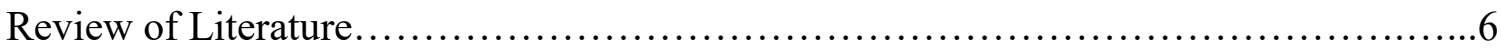

Chapter 3

Methods.................................................................. 16

Chapter 4

Results...................................................................19

Chapter 5

Discussion..............................................................29

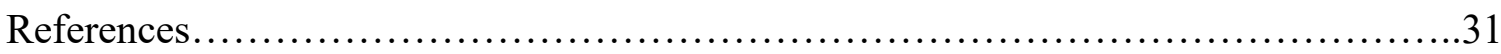

Appendix A. Satisfaction with Life Scale...................................... 36

Appendix B. Athletic history and current sports demands.......................................37

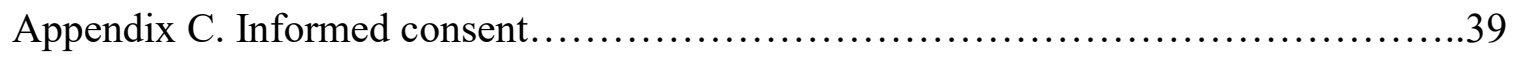

Appendix D. Human Subjects Approval........................................41 
List of Tables

1. Satisfaction with Life Scale Key............................................ 19

2. Linfield College and Portland State University descriptive data compared.............21

3. Statistically significant data separated by institution........................... 21

4. Statistical analysis comparing Linfield College and Portland State University.......22

5. Statistical analysis comparing Linfield College and Portland State University cont....22

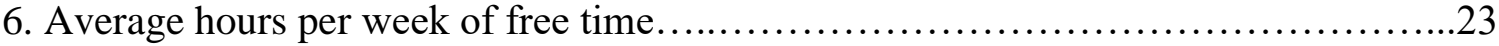

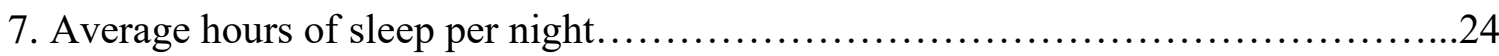

8. Amount of perceived control............................................. 25

9. Average hours of sleep per night compared to perceived control..................26

10. Descriptive statistics for SWLS, level of control and average hours of sleep.........27

11. Correlation between SWLS, level of control and average hours of sleep............28 
List of Figures

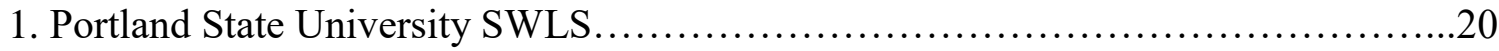

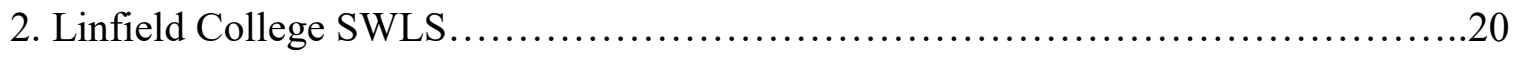

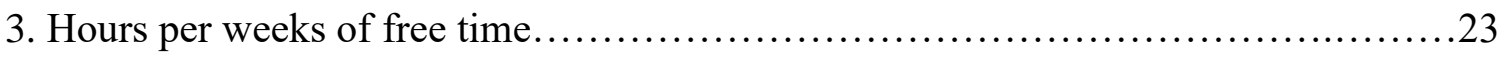

4. Average hours per night of sleep.............................................. 24

5. Levels of perceived life control................................................

6. Average hours of sleep per night compared to level of perceived control............27 


\section{Chapter 1}

\section{Introduction}

Life satisfaction is defined as a global feeling of contentment, fulfillment, or happiness with life in general (Diener, Emmons, Larsen \& Griffin, 1985). Life satisfaction is an aspect of everyone's lives, but is not something often thought about. Many do not take the time to sit and consider to what degree they are satisfied in their lives. However, life satisfaction is something that effects our life in many ways. For starters, low levels of life satisfaction have been directly related to increased high levels of self-reported stress (Weinstein and Laverghetta 2009). When experienced and perceived high levels stress and low life satisfaction are contributors to each other (Weinstein and Laverghetta, 2009). Both stress and low life satisfaction scores have been linked to a wide range of mental and physical poor health outcomes (American Psychological Association, 2013) (Korkeila et al., 1998; Loivumaa-Honkanen et al., 2002; Koivumaa-Honkanen et al., 2004; Mossey \& Shapiro 1982). Even without stress as a contributor, low levels of life satisfaction are associated with poor health outcomes (Korkeila et al., 1998; Loivumaa-Honkanen et al., 2002; Koivumaa-Honkanen et al., 2004; Mossey \& Shapiro 1982). It stands to reason that determining what the root of increased stress and low life satisfaction level would be beneficial to the overall health outcomes of the general population. The challenge becomes determining which experiences are contributing to increased levels of perceived stress. These factors change across varying populations and subpopulations, as well as on an individual basis.

One important reason for undertaking this research is the impact that low levels of life satisfaction can have on an individual's mental health. A literature review for this 
study found evidence suggesting that negative life satisfaction is associated with an increased risk of depression. This is an outcome of not only current negative life satisfaction, but past negative life satisfaction as well (Koivunaa-Honkanen, Kaprio, Honkanen, Viiamaki \& Koskenvuo, 2004). In other words, low life satisfaction could be a predictor of depression in the future (Koivunaa-Honkanen, Honkanen, Viinamaki, Heikkila, Kaprio \& Koskenvuo, 2000). It has been suggested that the events of an athlete's college career can influence success and life satisfaction into adulthood (Serbu, 1997). This is of extreme concern to those in the athletic training field as part of their job is to limit negative future health outcomes related to sport. As the consideration of the whole athlete is becoming more of the norm, life satisfaction and its outcomes as related to athletic participation is something that need to be taken into consideration when treating and training the student-athlete. If it is found that student-athletes are experiencing low life satisfaction it is important to take action in moderating that. More importantly, it is necessary to determine what is causing their low life satisfaction and doing what we can to lessen that demand or stressor.

In addition to the mental health concerns, low levels of life satisfaction and perceived well-being have also been linked to diminished health and high levels of mortality. This, in part, is thought to be due to an increase in poor health behaviors (Koivunaa-Honkanen et al., 2000). Life satisfaction is also important to injured athletes, as low levels of life satisfaction have been associated with poor rehabilitation behaviors (Malinauskas, 2010).

General population college students experience stress at varying degrees. Some stressors for those pursuing their bachelor's degree may include academic demands, lack 
of sleep and new life changes (i.e. moving away from home, living away from family, leaving established relationships, etc.). While being a college student may in and of itself be enough to cause an increase amount of stress, the collegiate student-athlete experiences additional athletics related demands and stressors. It is important to determine if these demands are contributing to a lower life satisfaction and if this happening across varying levels of collegiate play.

The life of a collegiate athlete from an outsider's perspective can give an impression of excitement and grandeur. Media often focus their reports on field success, painting a one-dimensional picture of the student-athlete. This can lead one to presume all student-athletes lead happy, satisfied lives. However, what if that presumption is wrong and these athletes are experiencing low life satisfaction and sense of well-being?

Student-athletes encounter a different four-year collegiate experience than their non-athlete counterparts. Their perception of this experience and subsequent life satisfaction may differ from their non-athlete counterparts as well. Research in this area of study deserves attention. Although studies have been performed that address nonathlete life satisfaction and former athlete satisfaction, research investigating the life satisfaction levels of current collegiate student-athletes is sparse. Considering the direct connection between high levels of stress and low life satisfaction, and the negative health outcomes that accompany both, it is important to look into what levels of life satisfaction collegiate student-athletes are experiencing. In addition, it is important to explore what factors may be contributing.

Purpose 
Research regarding this area of study deserves attention. Although studies have been performed that address non-athlete life satisfaction and former athlete life satisfaction, research investigating the life satisfaction of current student-athletes is sparse. Going a step further, in during the course of researching this topic the author was unable to find any research directly evaluating football players' life satisfaction, or comparing general athletes or football players of different division levels.

The NCAA places the limit on the number of "required" hours per week that an athlete spends participating in their sport at 20 hours while in season and eight hours out of season ("Countable Athletically Related Activities"). However, from anecdotal experience football players spend significantly more time devoted to their sport. When activities not listed by the NCAA as athletically related, such as injury treatment, are necessary this number increase even more. The time spent in sport seems to increase as the division level increases (with DI being the highest). Along with high time demands, collegiate athletes also have a limited amount of control over their lives. Much of their days are scheduled for them, the control they have over class schedules is limited, their ability to hold a job outside of school is limited, even elements of their physical appearance can be controlled by their coaches. This high level of external control is observed more the higher the division level. Division I and I AA athletics tend to be focused primarily on the student as an athlete and expect the athletes to display a high level of commitment. Division III programs, on the other hand, are much more focused on the student-athlete as a well-rounded individual, placing greater importance on their academic and college experience as a whole ("The Difference in the College Division Levels"). As the increase in sport related activities increases and time towards school and 
free time decreases, it is reasonable to think the student-athletes' levels of life satisfaction would decrease.

It is the hypothesis of study that athletes participating in DIII football will have a higher overall SWLS than their DI AA counterparts. It is also expected that athletes who report having less feeling of control over their lives will have a decreased level of life satisfaction compared to those who feel like they have more control. 
Chapter 2

\section{Review of Literature}

In order to understand the importance of administering and evaluating the SWLS in current collegiate student-athletes one must first understand what it means to experience low life satisfaction. Life satisfaction is the global feeling of contentment, fulfillment, or happiness with life in general (Diener, Emmons, Larsen \& Griffin, 1985). There are many factors related to life satisfaction that should be explored to build a full picture. It is also important to explore some mediating factors, should they exist, to help counteract the harmful effects of low life satisfaction.

\section{Health Effects of Subjective Life Satisfaction}

There have been numerous studies investigating the health effects of life satisfaction and subjective well-being. Understandably, the bulk of this research is concerned with the consequences of low life satisfaction. One such consequence is increased stress. In a study done by Weinstein and Laverghetta (2009) and incerse relationship was found between reported life satisfaction and perceived stress. Because of its relationship to stress, there are many health outcomes of life satisfaction that are secondary to that increase of stress. Stress - both acute and chronic - is associated with a myriad of both mental and physical conditions, including depression, gastrointestinal distress, heart disease, headaches, heart attacks, disordered eating, and the inability to concentrate (American Psychological Association, 2013). While these conditions are relevant for any group, there are additional circumstances that need to be considered for the student-athlete because of the additional physical and psychological demands placed on them. It is important for athletes to be in top physical shape in order to compete to the 
best of their ability. Health issues such as gastrointestinal distress and chronic headaches would present an obvious challenge to a student-athlete, and could presumably interfere with their athletic success. The psychological effects of stress also pose a problem for the student-athlete, as the inability to concentrate can negatively affect their performance. In addition, if they participate in a contact sport such as football, this diminished level of concentration can put them at an increased risk of physical injury.

Even without the effects of increased stress, low life satisfaction has been directly linked to negative health outcomes. Low life satisfaction has been linked to poor health behaviors (Koivumaa-Honkanen et al., 2000; Koivumaa-Honkanen et al., 2001) depressive symptoms (Koivumaa-Honkanen et al., 2004; Koivumaa-Honkanen et al., 2001), as well as poor health outcomes (Korkeila et al., 1998; Loivumaa-Honkanen et al., 2002; Koivumaa-Honkanen et al., 2004; Mossey \& Shapiro 1982).

One specific poor health behavior effected by low life satisfaction and high reported stress is alcohol consumption. A study done by Miles, et al. (2018) examined self-reported alcohol consumption and alcohol-related problem in 6705 Dutch adults registered at the Netherlands Twin Register between 18-83 years of age. Miles and his colleagues found that, while high risk and low life satisfaction was not necessarily related to volume of alcohol intake, they were associated with an increase in alcohol-related problems. Examples of alcohol-related problems included in this study are alcoholrelated injuries, guilt after drinking and blackouts. Age was shown to be a factor in outcomes as older individuals reported higher alcohol consumption but less alcoholrelated problems than their younger counterparts were. Miles et al. (2018) related this to older age individuals drinking more throughout the week and younger adults consuming 
alcohol over a shorter period. This is especially interesting as these subjects are closely related in age to those participating in collegiate athletics.

A more alarming issue in these reports was the possible causal link found between low levels of life satisfaction and early mortality. Koivumaa-Honkanen et al. (2000) studied healthy Finnish adults to examine self-reported life satisfaction and morbidity over a 20 -year period. They found that males classified as dissatisfied with their lives had an increased mortality, even when they controlled for death caused by both injury and disease. One may also be able to make a connection between low life satisfaction and risky behavior, as the association between low life satisfaction and injury mortality remained even after the exclusion of suicides (Koivumaa-Honkanen et al., 2000). That being said, Koivumma-Honkanen et al. (2001) found an alarming association between low life satisfaction and risk of suicide. Over a 20-year follow-up, dissatisfaction with life was found to be associated with higher risk of suicide. It is important to note that the subjects in this study did not have of any mental disorders.

It is clear though the studies outlined in this section that life satisfaction is strongly related to health outcomes. There is no reason to believe that student-athletes with low life satisfaction would be exempt from these outcomes.

\section{Depression and Life Satisfaction}

It is safe to say there is a high negative correlation between life satisfaction and depression, which is to say that those experiencing depressive symptoms are also reporting low levels of life satisfaction. (Heady, Kelley, \& Wearing, 1993). A prospective cohort study by Koivumaa-Honkanen et al. (2004) showed dissatisfaction continued to be a strong predictor of depressive symptoms during a 15-year follow-up. 
The study by Koivumma-Honkanen et al was a prospective cohort study based off the Finnish Twin Cohort. The study sample was comprised of 3984 male and 4480 female twins with a mean baseline age of 28.6 and 27.7, years respectively. Baseline questionnaires were sent out in 1975 with follow-up questionnaires sent out in 1981 and again in 1990. Authors used the life satisfaction scale to evaluate the subjects' level of life satisfaction, and the Beck Depression Inventory to assess the subjects' depressive state. It was found that both past and present reports of low satisfaction proved to be "strong, statistically significant predictors of depressive symptoms" (KoivumaaHonkanen et al., 2004, p.996). In an earlier study done by Koivumaa-Honkanen et al. (2001) it was found that in 188 of depressive patients depressive symptoms improved in conjunction with life satisfaction. Also, those who did not experience a decrease in their depressive symptoms also didn't experience an increase in their levels of life satisfaction. It should not be thought that participation in sport is protective against experiencing depressive symptoms. A study done by Beable, Fulcher, Lee, \& Hamilton (2017) found that, in a study comprised of 187 elite athletes, $21 \%$ of athletes surveyed were considered to have reported moderate levels of depression. In the same population, $8.6 \%$ of those surveyed reached levels of a major depressive episode. The three highest scoring of items identified as being a "hassle" were not getting enough sleep, concerns about meeting high standards and troubling thought about the future (Beable, Fulcher, Lee, \& Hamilton, 2017). While athletes included in this study were not student-athletes, it would be realistic to think that they may experience some of the same hassles. Along with daily stresses, participation demographics may also contribute to the experience of 
depression. Those competing in individual sports have been found to be 4.2 times more likely to experience depressive symptoms (Beable, Fulcher, Lee, \& Hamilton, 2017).

\section{Life Satisfaction of the Non-Athlete College Student}

An understanding of the life satisfaction in the general college student population is important in the investigation of life satisfaction of collegiate athletes. Many variables can affect one's level of experienced life satisfaction. Influences on a student's life satisfaction come from both internal and external variables and include such things as university facilities, time pressures, academia, interpersonal relationships, financial burden and low emotional intelligence (Kaya, Tansey, Melekoğlu, \& Çakiroğlu, 2015; Gnilka, Ashby, Matheny, Chung, \& Chang, 2015; Arslan \& Akkas, 2014; Holinka, 2015. While these stressors are numerous, there are also influences that attempt to decrease their effect on life satisfaction. Adequate coping resources, social satisfaction and high emotional intelligence all correspond with heightened levels of life satisfaction (Gnilka et al., 2015; Holinka, 2015; Arslan \& Akkas, 2014). Consistent with findings in general populations, life satisfaction in college students is also significantly related to depression (Pilcher, 1998). The same study found that frequency of health disturbances in this otherwise healthy population may have a stronger effect on life satisfaction than physical health. It would be interested to see where athletic injury would land on this injury and illness spectrum. Since athletic injury is regular part of sport, and some injuries force athletes to stop playing their sport, for varying amounts of time, student-athletes may experience a different relationship in regards to their physical health. 
A student's background prior to attending college has also been shown to have a significant impact on life satisfaction. Such characteristics include the student's socioeconomic status and whether or not they are first generation college students (Jenkins, Belanger, Connally, Boals \& Durón, 2013). Martinez, Sher, Krull \& Wood (2009) and Pascarella, Pierson, Wolniak \& Terenzini (2004) stated that undergraduate students who are the first in their families to go to college face additional challenges that others do not. As of 2016, $16 \%$ of NCAA student-athletes are the first in their families to go to college, with football having the highest percentage first generation student-athletes at 25\% (Smeyers@ncaa.org, 2016). The demands placed on those from lower socioeconomic backgrounds or those considered in the racial or ethnic minority also experience additional stressors (Lott, 2004). Student-athletes from racially or ethnically diverse backgrounds make up 34\% (16\% “black”, 18\% “other”) of NCAA studentathletes (National Collegiate Athletic Association, 2018). According to the number of both first generation and racial or ethnic minority student-athletes participating in the NCAA, a significant number of student-athletes may be experiencing additional stressors separate from both general school stressors experienced by the general student population and those related to athletic participation.

That is not to say that the demands placed on college students is entirely negative. Many college students actually experience higher levels of satisfaction with increasing demands (Bailey \& Miller, 1998). However, it is important to note that stressors themselves were measured rather than perceived stress.

\section{Life Satisfaction of Former Athletes}


While research is sparse, there have been some published reports on former athletes and their life satisfaction after formal participation in their sport. One study of life satisfaction involved former elite athletes (Martin, Fogarty \& Albion, 2014), where others concerned former collegiate athletes and focused on employment and education (Serbu, 1997; Kleiber \& Malik, 1989). Neither of these studies made a comparison between collegiate athletes competing in different NCAA divisions (e.g., Division I and Division III).

The amount of time the average athlete spends participating in formal competition is relatively short. When examining the life satisfaction of athletes who are no longer participating in athletics, an important aspect to consider is whether or not the cessation of participation was voluntary (Martin et al., 2014). According to Stambulova (2000) and Taylor and Ogilvie (1994) (as cited in Martin et al. 2014, p. 97) injury and being "cut" from a team without subsequently being picked up by another team are examples of involuntary retirement. Martin et al. (2014) found that athletes who choose to retire and prepare in advance experience higher levels of life satisfaction compared to those who are forced into retirement and do not prepare for the transition. It could be suggested that graduation from college can be considered a form of involuntary retirement, as less than $2 \%$ of athletes competing in NCAA sports end up of continuing to participate in a professional career in their sport ("NCAA Recruiting Facts", 2018).

When comparing collegiate athletes to professional athletes it is important to consider the additional role of "student" in the former group. This difference can affect the level of life satisfaction they experience later in life. It has been suggested that the athlete who is less involved in their academic career will experience lower levels of life 
satisfaction later in life (Kleiber \& Malik 1989). This is not to mean that participating in athletics in college sets the student-athlete up for lower life satisfaction and to be dissatisfied later in life. On the contrary, Serbu (1997) found that of former athletes surveyed, $63 \%$ reported being satisfied with their lives. Another $35 \%$ reported being "extremely satisfied" with their lives. Though both of these studies involved former collegiate athletes, neither compared different levels of competition (i.e., NCAA Division I vs. NCAA Division III).

\section{Sleep and Life Satisfaction}

When considering the connection between sleep and life satisfaction, it can be looked at one of two ways: what quantity of sleep is being had, or what quality of sleep is being had. A majority of research found in this area consisted of measuring quality of sleep. In a study done by Paunio, et al., 2008, it was found that while quality of sleep was most significantly connected to higher levels of life satisfaction, sleep length on its own also had a positive effect, while modest, on levels of life satisfaction. It was also found in this study that the quality of sleep was a predictor of not only current, but future life satisfaction, as the longitudinal study was completed over a six year span. It has been suggested that the relationship between poor sleep and low life satisfaction could be causal in either direction, i.e. poor sleep could cause lower levels of life satisfaction, or the state of being less satisfied causes poor sleep (Litwic-Kaminska \& Kotysko, 2017).

Sleep duration, when looked at independently from quality, has also been found to have a significant relationship with life satisfaction (Chan, Poon, Leung, Lau, \& Lau, 2018; Paunio, et al., 2008; Piper, 2015). In looking at high school students whose 
schedules were changed to allow a later wakeup time, more hours of sleep was found to be a predictor of higher life satisfaction (Chan, Poon, Leung, Lau, \& Lau, 2018). A study done by Piper, 2015 found that not only was sleep length in and of itself important for higher levels of life satisfaction, but that too much sleep can also result in decreased satisfaction levels. Piper, 2015 states that 8 hours is the optimal number of hours for experiencing the maximum level of life satisfaction.

\section{Perceived Control and Life Satisfaction}

Having control in one's life, or maybe more importantly having a perception of control, can have effects on both mental and physical health including stress and mortality (Heidemeier \& Göritz, 2013; Holden, Forester, Williford, \& Reilly, 2019; Hülür, et al., 2017; Infurna, Gerstorf, Ram, Schupp, \& Wagner, 2011). Hülür, et al., 2017 and Infurna, Gerstorf, Ram, Schupp, \& Wagner, 2011 found that the presence of higher levels of perceived internal control decreased the risk of mortality and disability. Higher levels of perceived control even acted as a mitigating factor for the risk of early death at all levels of experienced life satisfaction, though these effects ceased when a rapid decline of life satisfaction was present (Hülür, et al., 2017). These levels of control are reinforced by social factors such as community participation, interaction within your social group and general social interaction. In this instance, the high amounts of time athletes spend with their team may help contribute to higher levels of life satisfaction. These studies suggest that the perception of having control over one's life can increase positive health outcomes. An increase in life satisfaction has been found to be one such health outcome (Heidemeier \& Göritz, 2013). However, it was also found by Heidemeier \& Göritz, 2013, that while increased levels of internal control under normal 
circumstances leads to higher life satisfaction, when accompanied by the loss of a job that same increased amount of internal perceived control actually leads to lower levels of life satisfaction. This happens when internal perceived control is high and external perceived control is high. This may be relevant to an athletic population when considering forced retirement from sport due to injury, aging out or ability based cuts. 


\section{Chapter 3}

\section{Methods}

\section{Participants}

Two hundred-nineteen collegiate football players currently participating at Division I AA and Division III football programs were contacted to participate voluntarily in this study (107 from DI AA and 112 from DIII). Forty-six of those contacted chose to participate (22- Division 1 AA, 19- Division III and 5- unidentified). Responses lacking a division delineation were excluded from data analysis. All subjects were male as, in this particular season, all athletes participating on each team was male. Respondents were surveyed in the fall of 2019, while actively participating in their football seasons.

\section{Materials and Procedure}

The dependent variable in this study is satisfaction with life, as measured by the Satisfaction with Life Scale (SWLS) (Diener, Emmons, Larsen \& Griffin, 1985) (Appendix A). This is a 5 item questionnaire designed to assess the degree to which respondents are satisfied with their lives. Subjects rate their answers on a Likert-type 1-7 scale, ranging from 1 (strongly disagree) to 7 (strongly agree). Scores are totaled to determine final satisfaction with life score. Scores of 20 represent neutral with scores of 5-9 representing an extremely dissatisfied score and 15 to 19 representing slight dissatisfaction with life. Scores of 21-25 and 31-35 represent respondents slightly satisfied and extremely satisfied with life respectively (Diener et al., 1985; McDowell, 2010). The SWLS has been shown to be valid in a number of studies (Pavot \& Diener, 1993; Pavot \& Diener, 2008) as cited in McDowell (2010). 
In addition to the SWLS, the survey included an athlete history and current sports demands questionnaire (Appendix B) specifically designed for this study to address the athletes' current level of sport specific demands, as well as their past athletic experience. In addressing current sport demands, athletes were asked to provide information regarding current institution, hours spent devoted to sport, and current level of athletic satisfaction as compared to past athletic satisfaction. Questions addressing past athletic experience included age of sport specialization, history of sport variety and age at which participation in organized sport began. This portion of the survey also contains questions regarding athlete sleep and free time. This information was collected to identify characteristics that may differentiate one the experience at one division level from the other, as well as inform future research.

To recruit subjects for this study the author contacted head coaches from each the two football programs in Northwestern Oregon (1-DI AA and 1-DIII) for their permission and cooperation in surveying their athletes. Student athletes were contact through their coaches via email. The recruitment email contained a link to the survey as well as a brief explanation of the survey and notification that their participation was voluntary. After clicking on the link they were directed to the Survey Monkey website on which the survey was conducted. Before beginning the survey, participants were first asked to read, and agree to, a letter of informed consent (Appendix C). They were again reminded that their participation was strictly mandatory and anonymous. Failure to consent to participation in the study would result in the subject being exited from the survey. The average time spent completing the survey was 4 minutes and 17 seconds. The athletes were able to complete the surveys at the time of their choosing. This survey was 
distributed around the midpoint of football season, possibly accounting for some of the lack of participation. 


\section{Chapter 4}

Results

The results for this study were collected and organized via Survey Monkey website software. Data was analyzed utilizing the SPSS data analysis program. Pearson correlation and Sig. (2-tailed) were used to determine the presence, or lack of, significant correlations. Data collected did not support part one of original hypothesis. Possible reasons will be addressed in the discussion potion of this paper.

\section{Analysis part 1 \\ Portland State University vs. Linfield College}

When adding the weighted average of responses, the SWLS of Portland State University (Figure 1) and Linfield College (Figure 2) were within 1.23 points of each other, and both fell within the "slightly satisfied" range of the SWLS. A key to the SWLS scoring can be found in Table 1. The additional data obtained from the subjects were also very similar between the two teams. For this reason, and due to the small sample size of data, the author chose to combine the two groups to assess possible contributing factors. The contributing factor data, while not statistically significant, has been included (Table 2). The statistical analysis comparing the two institutions is contained tables 4-5.

Table 1

\begin{tabular}{|c|c|c|c|c|c|c|}
\hline \multicolumn{7}{|c|}{ SWLS Scoring Key } \\
\hline 1 & 2 & 3 & 4 & 5 & 6 & 7 \\
\hline $\begin{array}{l}\text { Strongly } \\
\text { Disagree }\end{array}$ & Disagree & $\begin{array}{l}\text { Slightly } \\
\text { Disagree }\end{array}$ & $\begin{array}{l}\text { Neither } \\
\text { agree nor } \\
\text { disagree }\end{array}$ & $\begin{array}{l}\text { Slightly } \\
\text { Agree }\end{array}$ & Agree & $\begin{array}{l}\text { Strongly } \\
\text { Agree }\end{array}$ \\
\hline
\end{tabular}


Figure 1- SWLS Portland State University

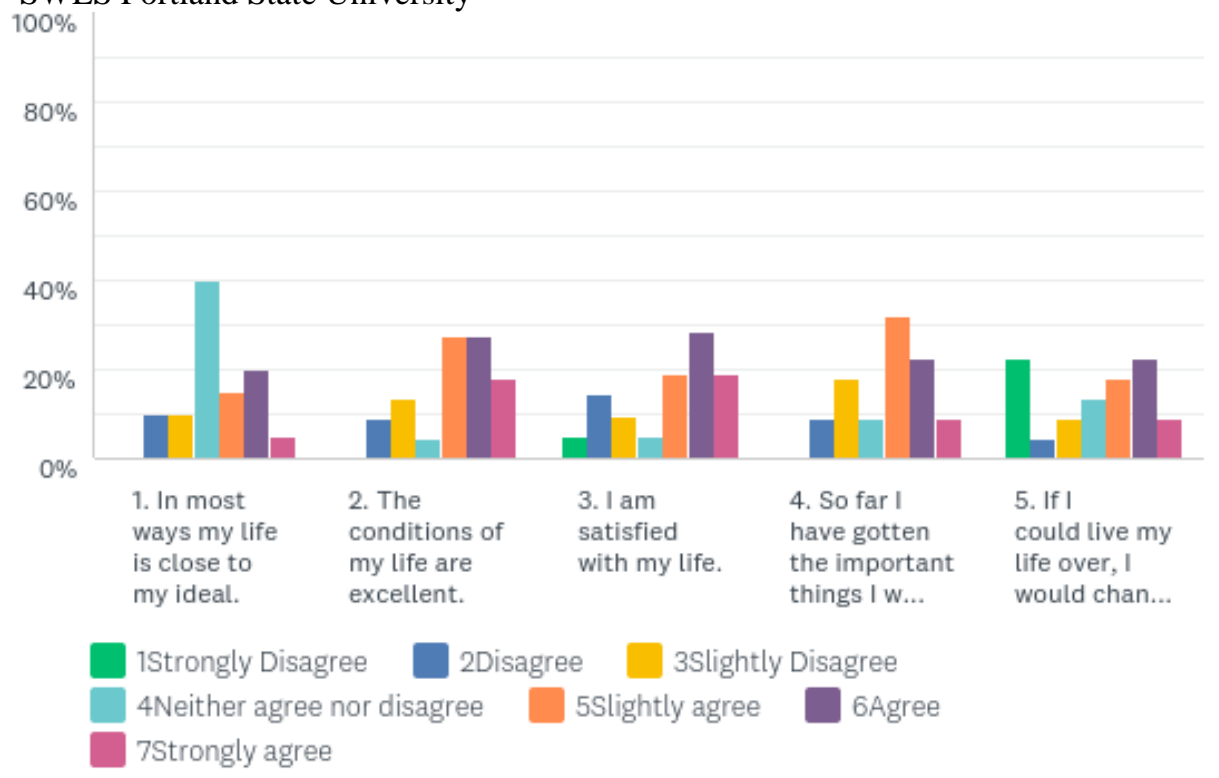

Figure 2- SWLS Linfield College

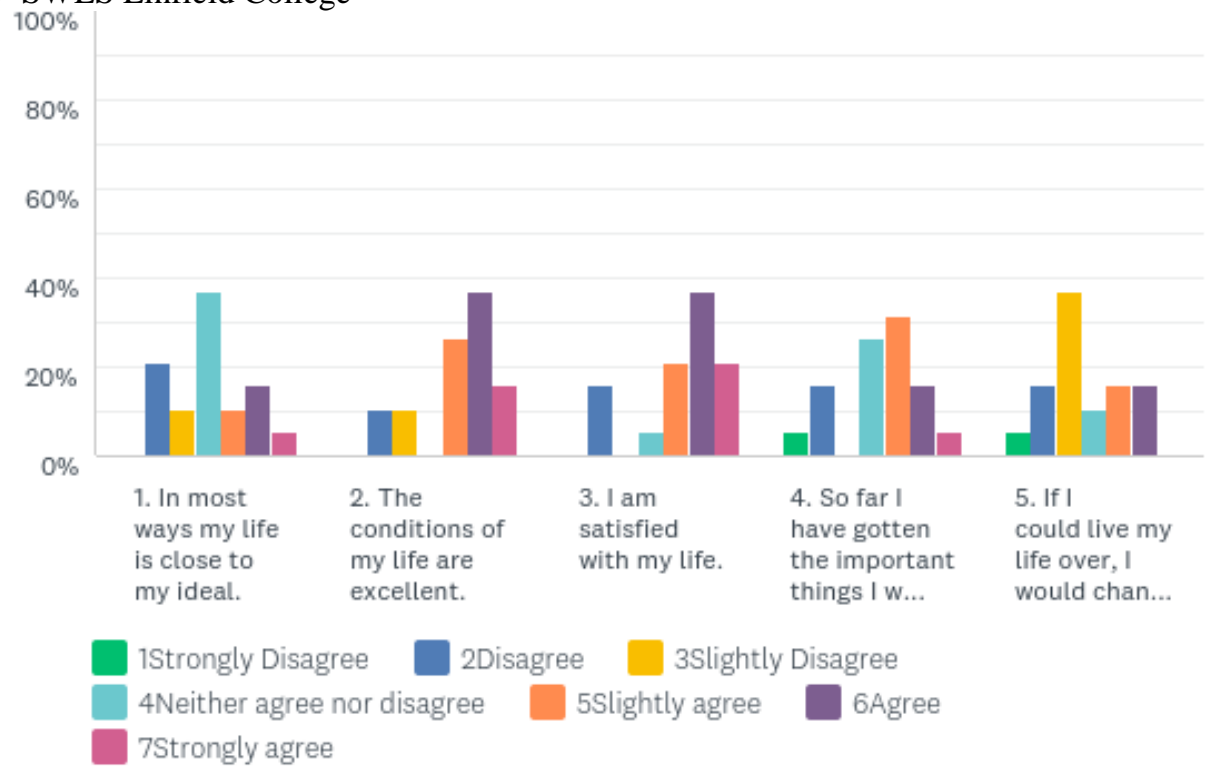


Table 2- Compared descriptive data PSU vs Linfield

\begin{tabular}{r|lll} 
School & $N$ & Est. Mean & Std. Deviation \\
\hline Yr. Eligibility: PSU & 22 & 3.6818 & 1.5240 \\
Linfield & 19 & 3.1053 & 1.1496 \\
Yrs. in current program: & & & \\
Linfield & 22 & 2.5455 & 1.2622 \\
PSU & 22 & 2.1053 & 1.1496 \\
Linfield & 19 & 3.9091 & 1.8493 \\
Division level started at: & & & \\
Number of colleges & & & \\
played for: & & & \\
PSU & 22 & 1.3182 & 0.5679 \\
Linfield & 19 & 1.0526 & 0.2294 \\
week: & & & \\
PSU & 22 & 8.2045 & 5.3177 \\
Linfield & 19 & 7.6316 & 5.0986 \\
Avg hrs free time per & & & \\
PSort: & & & \\
Linfield & 22 & 6.4091 & 3.1116 \\
Age starting organized & 19 & 5.8947 & 2.7263 \\
PSU & 22 & 10.8409 & 5.6682 \\
Linfield & 19 & 14.5263 & 3.1906 \\
Age of specialing in FB: & & & \\
Satisfaction with sport & & & \\
now vs. past: & & & \\
PSU & 22 & 1.9545 & 0.7674 \\
Linfield & 19 & 1.8421 & 0.8120
\end{tabular}

Table 3- Statistically significant data when combined, separated by institution

\begin{tabular}{r|llll} 
School & $N$ & Mean & Std. Deviation & $\begin{array}{l}\text { Std. Error } \\
\text { Mean }\end{array}$ \\
\hline SWLS: PSU & 20 & 22.9500 & 6.53311 & 1.46085 \\
Linfield & 19 & 22.4211 & 5.69908 & 1.30746 \\
PSU & 21 & 24.6429 & 11.31939 & 2.47009 \\
FB time in season: & & & \\
Linfield & 19 & 28.0000 & 8.26640 & 1.89644 \\
FB time out of & & & & \\
season: PSU & 19 & 13.16 & 9.651 & 2.214 \\
Linfield & 15 & 13.70 & 10.089 & 2.605 \\
Avg hrs sleep/night: & & & & \\
PSU & 22 & 6.0682 & 1.33001 & .28356 \\
Linfield & 19 & 6.5526 & 1.02598 & .23538 \\
PSU & 22 & 2.3182 & 1.08612 & .23156 \\
Perceived control: & & & .17631
\end{tabular}


Table 4- Statistical analysis comparing Linfield to Portland State University

\begin{tabular}{l|llll}
\multicolumn{2}{c}{ T } & Df & $\begin{array}{l}\text { Sig(2- } \\
\text { tailed) }\end{array}$ & Mean diff \\
\hline SWLS: Equal variance ass. & .269 & 37 & .790 & .52895 \\
Equal variance not ass. & .270 & 36.744 & .789 & .52895 \\
FB in season time: Equal variance ass. & -1.061 & 38 & .295 & -3.357 \\
Equal variance not ass. & -1.075 & 36.454 & .288 & -3.357 \\
& & & & \\
FB out of season time: Equal variance ass. & -.159 & 32 & .874 & -.542 \\
Equal variance not ass. & -.159 & 29.543 & .875 & -.542 \\
Avg hrs sleep/night: Equal variance ass. & -1.290 & 39 & .205 & -.4844 \\
Equal variance not ass. & -1.315 & 38.554 & .196 & -.4844 \\
Perceived control: Equal variance ass. & -.345 & 39 & .732 & -.1029 \\
Equal variance not ass. & -.353 & 37.646 & .726 & -.1029
\end{tabular}

Table 5- Statistical analysis comparing Linfield College to Portland State University cont.

\begin{tabular}{r|lll} 
& \multicolumn{1}{l}{$\begin{array}{l}\text { Std. } \\
\text { error diff }\end{array}$} & Lower & Upper \\
\hline SWLS: Equal variance ass. & 1.96751 & -3.45761 & 4.51550 \\
Equal variance not ass. & 1.96049 & -3.44432 & 4.50222 \\
FB in season time: Equal variance ass. & 3.16314 & -9.76059 & 3.04630 \\
Equal variance not ass. & 3.11414 & -9.67018 & 2.95589 \\
& & & \\
FB out of season time: Equal variance ass. & 3.400 & -7.468 & 6.384 \\
Equal variance not ass. & 3.419 & -7.529 & 6.444 \\
Avg hrs sleep/night: Equal variance ass. & .37561 & -1.24419 & .27529 \\
Equal variance not ass. & .36852 & -1.23013 & .26123 \\
Perceived control: Equal variance ass. & .29840 & -.70644 & .50070 \\
Equal variance not ass. & .29104 & -.69224 & .48650
\end{tabular}

\section{Analysis Part 2}

Due to the small sample size, and similar outcome of data, the two institutions were combined into one grouping for the remainder of the data analysis. The mean SWLS over the combined programs was 22.7500 with a standard deviation of 5.99893 (Table 10). 
Average hours of free time per week

One interesting discovery was the amount of free time per week the athletes reported having. Fifty percent of athletes reported having 0-7 hours of time not allocated to either football, school or self-care (sleeping, eating, etc.) (Table 6, Figure 3). While there was no statistical correlation found with this sample of subjects, it may be worth looking into this variable with a larger sample size.

Figure 3- Hours per week of free time

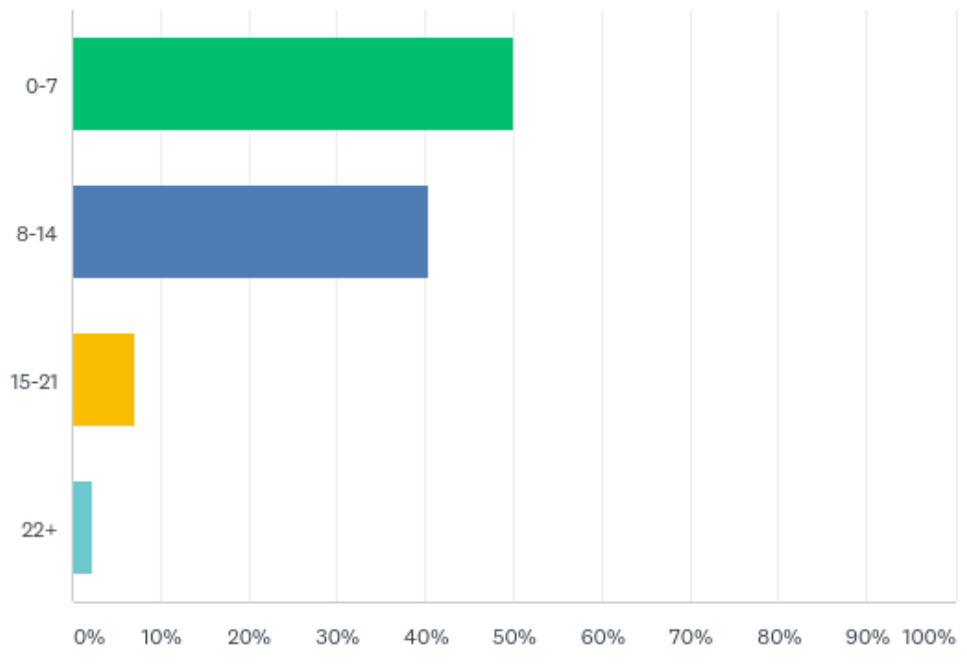

Table 6- Hours per week of free time

\begin{tabular}{|lll|}
\hline Hours of free time/week & Responses \\
\hline $\mathbf{0 - 7}$ & $50.00 \%$ & 21 \\
\hline $\mathbf{8 - 1 4}$ & $40.48 \%$ & 17 \\
\hline $\mathbf{1 5 - 2 1}$ & $7.14 \%$ & 3 \\
\hline $\mathbf{2 2 +}$ & $2.38 \%$ & 1 \\
\hline Total & & 42 \\
\hline
\end{tabular}


Average hours of sleep per night

It was also found that $57.14 \%$ of athletes get less than 7 hours of sleep per night (Table 7, Figure 4). As sleep is so important to both physical and mental health, this lack of the recommended 7 hours per night can also conceivably contribute to lower SWLS scores. The mean hours per night of sleep reported was 6.2738 with a standard deviation of 1.20062. It has been suggested that less than 7 hours of sleep per night contributes to lower levels of life satisfaction when compared with scores of those getting 8 hours of sleep (Paunio, et al., 2008). The significance and correlation of data collected regarding hour of sleep per night will be discussed further later in this section.

Figure 4- Average hours of sleep per night

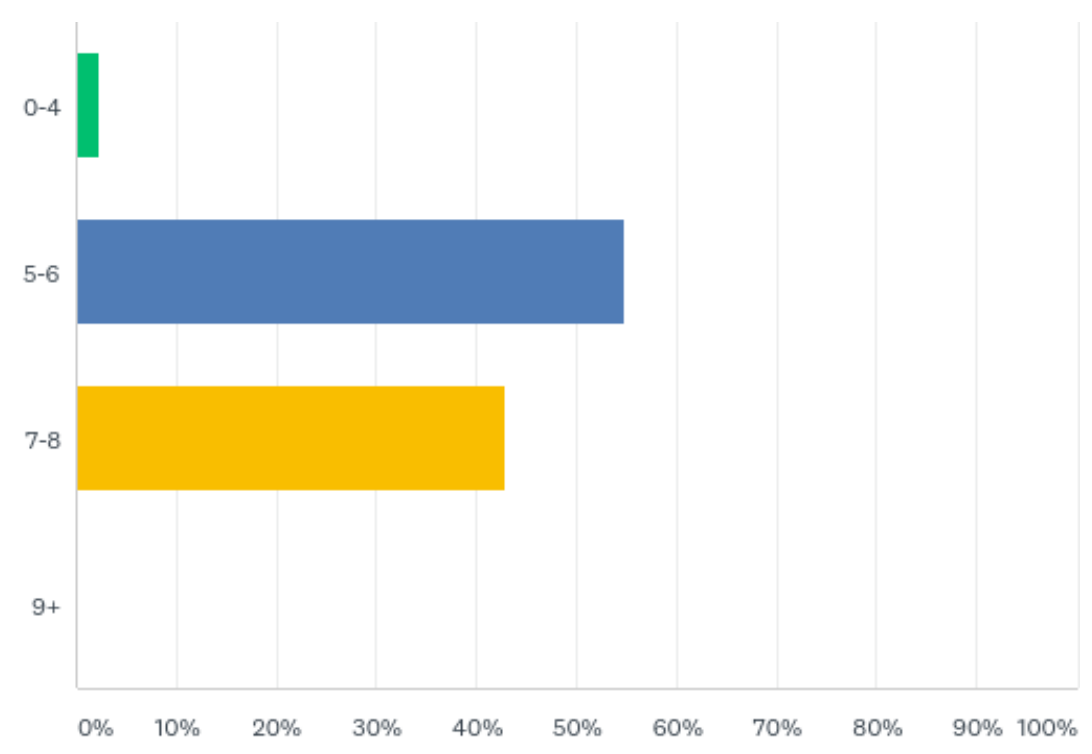

Table 7- Average hours of sleep per night

\begin{tabular}{|lll|}
\hline Hours of sleep/night & Responses & \\
\hline $\mathbf{0 - 4}$ & $2.38 \%$ & 23 \\
\hline $\mathbf{5 - 6}$ & $54.76 \%$ & 18 \\
\hline $\mathbf{7 - 8}$ & $42.86 \%$ & 0 \\
\hline $\mathbf{9 +}$ & $0.00 \%$ & 42 \\
\hline Total & & \\
\hline
\end{tabular}




\section{Levels of perceived control}

Reported perceived control ranged from feelings of full control to feelings of little control. A majority of data collected reflect level of control perceptions in the middle of the spectrum, with only $30.95 \%$ reporting feelings of either full or little control over their life, and zero reporting having feelings of no control (Table 8, Figure 5).

Figure 5- Amount of perceived life control

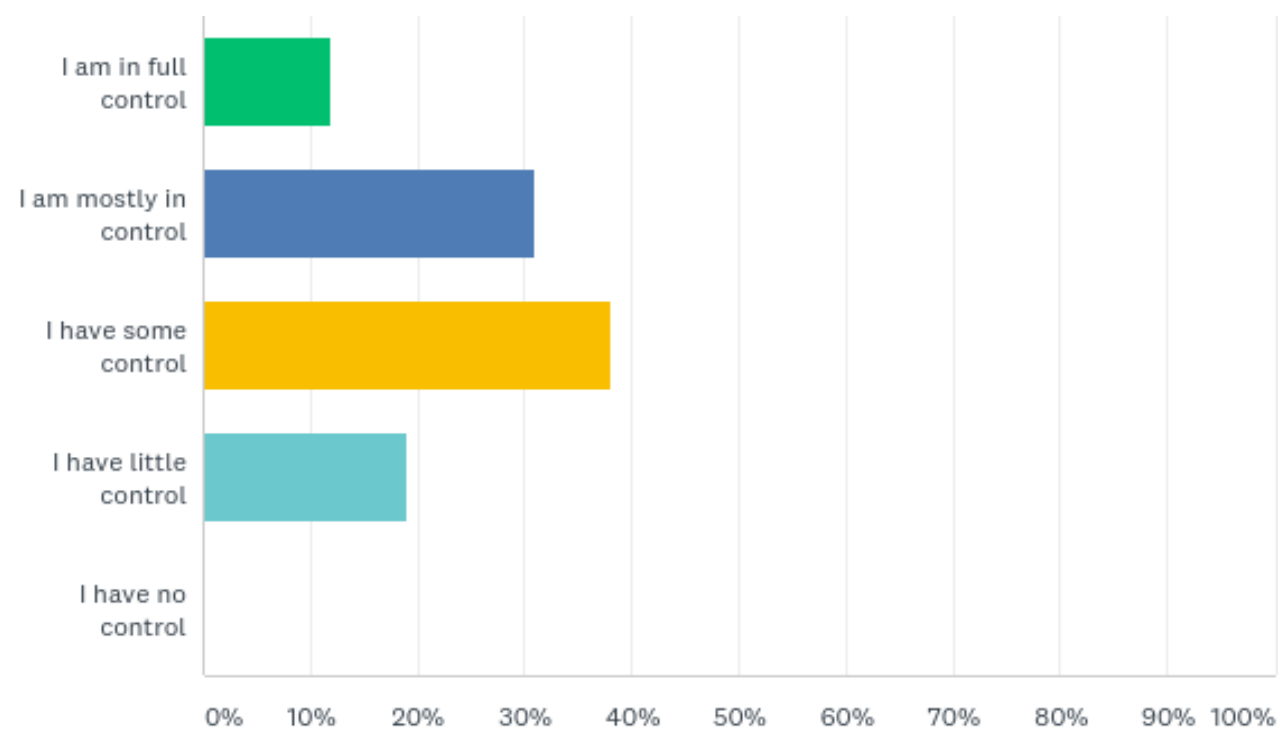

Table 8- Amount of percieved life control

How much control do you feel you have over your current life?

\begin{tabular}{|lll|}
\hline I am in full control & $11.90 \%$ & 5 \\
\hline I am mostly in control & $30.95 \%$ & 13 \\
\hline I have some control & $38.10 \%$ & 16 \\
\hline I have little control & $19.05 \%$ & 8 \\
\hline I have no control & $0.00 \%$ & 0 \\
\hline & Answered & 42 \\
\hline & Skipped & 5 \\
\hline
\end{tabular}


Sleep and perceived control

It was found in the course of this study that there was a positive significant relationship between the average hours of sleep athletes got per night and the amount of their perceived life control. Table 9 and Figure 6 outline the data collected reporting the average amount of sleep per night and comparing that to data collected reporting perceived control. Data analysis showed a significant correlation below the 0.05 level (2tailed) threshold between hours of sleep and perceived control. The Pearson Correlation value was calculated at .346 and Sig (2-tailed) was calculated at .025 (Table 10, Table 11). Data suggests that, as the student-athletes perceive higher levels of control over their lives, the more hours of sleep per night they are able to get. It is possible that the strength of this correlation may be diminished due to the small sample size.

Table 9-Average hours of sleep per night compared to level of perceived control

\begin{tabular}{|l|l|l|l|l|l|l|l|l|l|l|l|l|l|l|}
\hline $\begin{array}{l}\text { Hours of } \\
\text { sleep/night }\end{array}$ & $\begin{array}{l}\text { I am in full } \\
\text { control }\end{array}$ & \multicolumn{2}{l}{$\begin{array}{l}\text { I am mostly } \\
\text { in control }\end{array}$} & \multicolumn{2}{l}{$\begin{array}{l}\text { I have some } \\
\text { control }\end{array}$} & \multicolumn{2}{l}{$\begin{array}{l}\text { I have little } \\
\text { control }\end{array}$} & \multicolumn{2}{l}{$\begin{array}{l}\text { I have } \\
\text { no } \\
\text { control }\end{array}$} \\
\hline $\mathbf{0 - 4}$ & $0.00 \%$ & 0 & $0.00 \%$ & 0 & $0.00 \%$ & 0 & $100.00 \%$ & 1 & $0.00 \%$ & 0 & $2.38 \%$ & 1 \\
\hline $\mathbf{5 - 6}$ & $4.35 \%$ & 1 & $26.09 \%$ & 6 & $52.17 \%$ & 12 & $17.39 \%$ & 4 & $0.00 \%$ & 0 & $54.76 \%$ & 23 \\
\hline $\mathbf{7 - 8}$ & $22.22 \%$ & 4 & $38.89 \%$ & 7 & $22.22 \%$ & 4 & $16.67 \%$ & 3 & $0.00 \%$ & 0 & $42.86 \%$ & 18 \\
\hline $\mathbf{9 +}$ & $0.00 \%$ & 0 & $0.00 \%$ & 0 & $0.00 \%$ & 0 & $0.00 \%$ & 0 & $0.00 \%$ & 0 & $0.00 \%$ & 0 \\
\hline Total & $11.90 \%$ & 5 & $30.95 \%$ & 13 & $38.10 \%$ & 16 & $19.05 \%$ & 8 & $0.00 \%$ & 0 & $100.00 \%$ & 42 \\
\hline & & & & & & & & & & & Answered & $\mathbf{4 2}$ \\
\hline & & & & & & & & & & & Skipped & 0 \\
\hline
\end{tabular}


Figure 6- Average sleep per night compared to perceived level of control

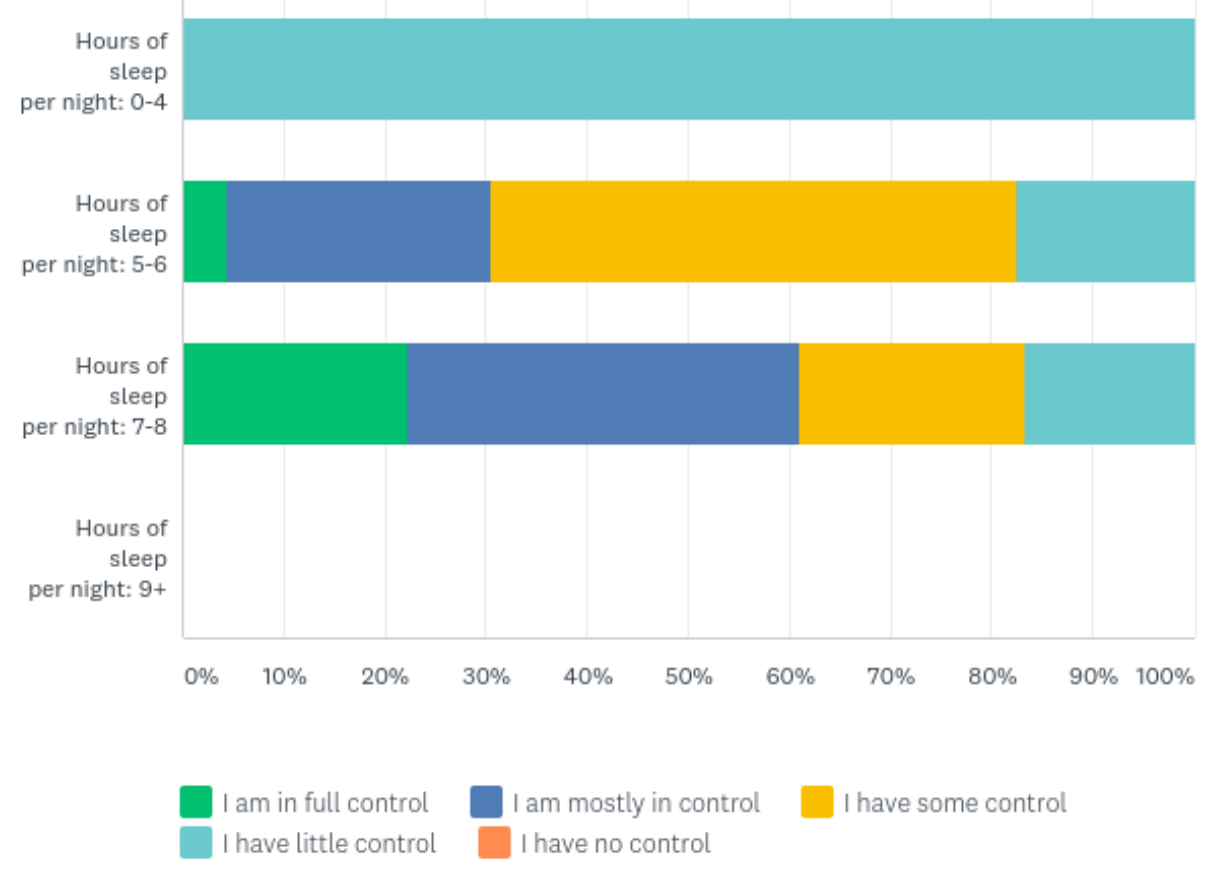

Table 10- Descriptive statistics for SWLS, Perceived control and Average hrs. of sleep/night

\begin{tabular}{r|lll} 
Question & Mean & Standard Deviation & $N$ \\
\hline SWLS & 22.7500 & 5.99893 & 40 \\
Perceived Control & 2.3571 & .93238 & 42 \\
Avg. sleep/night & 6.2738 & 1.20062 & 42
\end{tabular}


Table 11- Correlation between SWLS, perceived control and avg sleep/night

\begin{tabular}{|c|c|c|c|}
\hline & SWLS & Perceived Control & Avg. Sleep/night \\
\hline $\begin{array}{l}\text { SWLS } \\
\text { Pearson Correlation }\end{array}$ & 1 & $.603 * *$ & .262 \\
\hline Sig. (2 tailed) & & $0.00 * *$ & .102 \\
\hline $\mathrm{N}$ & & 40 & 40 \\
\hline Perceived Control & $.603 * *$ & 1 & $.346^{*}$ \\
\hline Sig. (2-tailed) & $0.00 * *$ & & $.025^{*}$ \\
\hline $\mathrm{N}$ & 40 & & 42 \\
\hline $\begin{array}{l}\text { Avg. Sleep/night } \\
\text { Pearson Correlation }\end{array}$ & .262 & $.346^{*}$ & 1 \\
\hline Sig. (2-tailed) & .102 & $.025^{*}$ & \\
\hline $\mathrm{N}$ & 40 & 42 & \\
\hline
\end{tabular}

** Correlation is significant at the 0.01 level (2-tailed), * Correlation is significant at the 0.05 level (2tailed)

SWLS and perceived control

Data collected for this study supports the secondary hypothesis that those athletes who percieved having less control over their lives experienced lower levels of life satisfaction. In comparing the two variables a positive Pearson Correlation value of .603 was calcuated, suggesting an increase in one variable would result in an increase in the other. A p-value of .000 was found, suggesting a strong significant correlation (Table 11). These numbers suggest that as the student-athlete feels increaing levels of control over their life they will also experience higher levels of life satisfaction. 


\section{Chapter 5}

\section{Discussion}

There were a number of limitations with this study, the biggest of which being the small sample size. A larger percentage of athltes from each institution completing the survey would have given a fuller picture of data. Not only does the small number of participants create an issue with deriving statistically significant results, but it begs the question of whether those who are willing to take the time to complete a voluntary online questionnaire are also more apt to be experiencing higher levels of life satisfaction. It would also be adventageous to collect data samples from multiple institutions at each level. This larger area of sampleling would help to control for characteristics specific to the individual athletic programs rather than the division in which they play, and give a truer picture of differences between division levels. Additional factors that were not controlled for include team success of current season, past team athletic success and characteristics of the individual institutions' environments. Due to the closeness in geography of the two institutions weather, though it may be a confounding factor, should be expereinced in the same way across the sample. However, there are a number of environmental difference that could have an effect on the life satisfaction of the subjects including urban vs. rural locations, diversity of student body and centralized vs. satalite campuses. It would also be worth looking into the number of student-athletes in each program that are from out of state vs. attending school within the same region in which they grew up.

Reasearch done preparing for this study showed a correlation between low life satisfaction and stress. For future research, it would be useful to include a stress specific 
questionnaire to assess if this correlation holds true to collegiate student-athletes. It would also be interesting to examine the relationship between athletes with scholarships and those without. Would receiving scholarship money decrease pressure on the athletes by eliminating some of the economic burden of college, or would it increase pressure to continue participation in their sport in order to not lose their scholarship money?

Another avenue that would be interesting to explore would be the history of concussion and injury in the individual respondents. Not only does concussion have a physical effect on the brain, but the experience of missing playing time and possibly even forced retirement from sport can effect the mental state of the athlete.

With the information learned from this study we can educate coaches, advisors and athletic trainers on both the importnace of life satisfaction and steps that can be taken to improve said satisfaction scores. Based on our findings some suggestions that may be given to coaches would be giving their athletes the opportunity to get at least 8 hours of sleep per night, encouraging them to take control over their academic careers and encouraging a positive social team environment. 


\section{References}

American Psychological Association. (2013). How stress affects your health. Retrieved from http:apa.org/helpcenter/stress.aspx

Arslan, S., \& Akkas, O. A. (2013). Quality of College Life (QCL) of Students in Turkey: Students' Life Satisfaction and Identification. Social Indicators Research, 115(2), 869884.

Bailey, R. C., \& Miller, C. (1998). Life Satisfaction And Life Demands In College Students. Social Behavior and Personality: an International Journal, 26(1), 51-56. doi: 10.2224/sbp.1998.26.1.51

Beable, S., Fulcher, M., Lee, A. C., \& Hamilton, B. (2017). SHARPSports mental Health Awareness Research Project: Prevalence and risk factors of depressive symptoms and life stress in elite athletes. Journal of Science and Medicine in Sport, 20, 1047-1052. Retrieved from http://dx.doi.org/10.1016/j.jsams.2017.04.2018

Chan, C. S., Poon, C. Y., Leung, J. C., Lau, K. N., \& Lau, E. Y. (2018). Delayed school start time is associated with better sleep, daytime functioning, and life satisfaction in residential high-school students. Journal of Adolescence, 66, 49-54. doi:

10.1016/j.adolescence.2018.05.002

Countable Athletically Related Activities. (n.d.). Retrieved from https://www.ncaa.org/sites/default/files/20-Hour-Rule-Document.pdf.

Diener, E., Emmons, R.A., Larsen R.J., \& Griffin, S. (1985). The Satisfaction with Life Scale. Journal of Personality Assessment, 49(1), 71-75.

Felton, L., \& Jowett, S. (2013). "What do coaches do" and "How do they relate": Their effects on athletes' psychological needs and functioning. Scandinavian Journal of Medicine \& Science in Sports, 23(2) 130-139.

Gnilka, P. B., Ashby, J. S., Matheny, K. B., Chung, Y. B., \& Chang Y. (2015). Comparison of coping, stress and life satisfaction between Taiwanese and U.S. college students. Journal of Mental Health Counseling, 37(3), 234-249.

Heady, B., Kelley, J., \& Wearing, A. (1993). Dimensions of Mental Health: Life Satisfaction, Positive Affect, Anxiety and Depression. Social Indicators Research, 29(1), 63-82. Retrieved from https://www/jstor.org/stable/27522681

Heidemeier, H., \& Göritz, A. S. (2013). Perceived control in low-control circumstances: Control beliefs predict a greater decrease in life satisfaction following job loss. Journal of Research in Personality, 47(1), 52-56. doi: 10.1016/j.jrp.2012.11.002 
Holden, S. L., Forester, B. E., Williford, H. N., \& Reilly, E. (2019). Sport Locus of Control and Perceived Stress among College Student-Athletes. International Journal of Environmental Research and Public Health, 16(16), 2823. doi: 10.3390/ijerph16162823

Holinka, C. (2015). Stress, emotional intelligence, and life satisfaction in college students. College Student Journal, 49(2), 300-311.

Hülür, G., Heckhausen, J., Hoppmann, C. A., Infurna, F. J., Wagner, G. G., Ram, N., \& Gerstorf, D. (2017). Levels of and changes in life satisfaction predict mortality hazards: Disentangling the role of physical health, perceived control, and social orientation. Psychology and Aging, 32(6), 507-520. doi: 10.1037/pag0000187

Infurna, F. J., Gerstorf, D., Ram, N., Schupp, J., \& Wagner, G. G. (2011). Long-Term Antecedents and Outcomes of Perceived Control. SSRN Electronic Journal. doi: $10.2139 /$ ssrn. 1750253

Jenkins, R.J., Belanger, A., Connally, M.L., Boals, A., \& Durón, K.M. (2013). Firstgeneration undergraduate students' social support, depression, and life satisfaction. Journal of College Counseling (16) 129-142.

Jenkins, S.R., Belanger, A., Connally, M.L., Boals, A., \& Durón, K.M. (2013). Firstgeneration undergraduate students' social support, depression, and life satisfaction. Journal of College Counseling, 16, 129-142.

Kaprio, J., Koskenvuo, M., Langinvainio H., et al. (1987) Psychosocial factors and morbidity: hospitalization and mortality in the Finnish twin cohort. Basic tabulations of a six year follow-up of 31116 Finnish adults. Helsinki, Finland: Department of Public Health, University of Helsinki. (Public Health publication no. M99).

Kaya, C., Tansey, T. N., Melekoğlu, M., \& Çakiroğlu, O. (2015). Stress and life satisfaction of Turkish college students. College Student Journal, 49(2) 257-261.

Kleiber, D. A. (1989). Educational involvement of college athletes and subsequent wellbeing in early adulthood. Journal of sport behavior, 12(4), 203-211.

Klemmack, D. L., Carlson, J. R., \& Edwards, J. N. (1974). Measures of well-being: An empirical and critical assessment. Journal of Health and Social Behavior, 15, 267-270.

Koivunaa-Honkanen H. T. (1998) Life satisfaction as health predictor. Kuopio, Finland: Kuopio University Publications. (Medical Sciences publication no D143).

Koivunaa-Honkanen, H., Honkanen, R., Viinamaki, H., Heikkila, K., Kaprio, J., \& Koskenvuo, M. (2000). Self-reported life satisfaction and 20-year mortality in healthy Finnish adults. American Journal of Epidemiology, 152(10), 983-991. 
Koivumaa-Honkanen, H., Honkanen, R., Anikainen, R., Hintikka, J., Laukkanen, E., Honkalampi, K., \& Viinamäki, H. (2001). Self-reported life satisfaction and recovery from depression in a 1-year prospective study. Acta Psychiatr Scand (103) 38-44.

Koivunaa-Honkanen, H., Honkanen, R., Viinamäki, H., Heikkila, K., Kaprio, J., \& Koskenvuo, M. (2001). Life satisfaction and suicide: A 20-year foll1ow-up study. American Journal of Psychiatry, 158 (3), 433-439.

Koivumaa-Honkanen, H., Honkanen, R., Viinamäki H., \& Kapiro J. (2002). Life dissatisfaction as a predictor of fatal injury in a 20-year follow-up. Acta Psychiatr Scand (105) 444-450.

Koivunaa-Honkanen, H., Kaprio, J., Honkanen, R., Viiamaki, H., \& Koskenvuo, M. (2004). Life satisfaction and depression in a 15-year follow-up of healthy adults. Soc Psychiatry Psychiatr Epidemiology, 39, 994-999.

Koivunaa-Honkanen, H. T., Viinamäki, H., Honkanen, R., et al. (1996). Correlates of life satisfaction among psychiatric patients. Acta Psychiatr Scand, 94, 372-378.

Korkeila, M., Kaprio, J., Rissanen, A., et al. (1998). Predictors of major weight gain in adult Finns: Stress, life satisfaction and personality traits. International Journal of Obesity, 22, 949-957.

Litwic-Kaminska, K., \& Kotysko, M. (2017). Comparison of good and poor sleepers: stress and life satisfaction of university athletes. Journal of Sport Psychology, 26(4), $121-126$

Lott, B., (2004). Violence in Low-Income Neighborhoods in the United States. Journal of Aggression, Maltreatment \& Trauma, 8:4, 1-15, DOI: 10.1300/ J146v08n04_01

Malinauskas, R. (2010). The associations among social support, stress, and life satisfaction as perceived by injured college athletes. Social behavior and personality, 38(6), 741-752.

Martin, L.A., Fogarty, G.J., \& Albion M.J. (2014). Changes in athletic identity and life satisfaction of elite athletes as a function of retirement status. Journal of Applied Sport Psychology, 26,1, 96-110.

McDowell, I. (2010). Measures of self-perceived well-being. Journal of Psychosomatic Research, 69, 69-79.

Martinez, J., Sher, K., Krull, J., \& Wood, P. (2009). Blue-collar scholars?: Mediators and moderators of university attrition in first-generation college students. Journal of College Student Development, 50, 87-103. 
Miles, G. W., Veriweij, K. J. H., Treur, J. L., Ligthart, L., Fedko, I. O., Hottenga, J. J., ... Vink, J. M. (2018). Polygenic risk for alcohol consumption and its association with alcohol-related phenotypes: Do stress and life satisfaction moderate these relationships? Drug and Alcohol Dependence, 183, 7-12. Retrieved from https://doi.org/10.1016/j.drugalcdep.2017.10.018

Mossey, J. M., \& Shaprio, E. (1982). Self-rated health: A predictor of mortality among the elderly. American Journal of Public Health, 72, 800-808.

National Collegiate Athletic Association. (2018). NCAA Demographics Database [Data visualization dashboard]. Retrieved from http://www.ncaa.org/about/resources/research/ncaa-demographics-database

NCAA Recruiting Facts. (2018, March). Retrieved November 17, 2019, from https://www.ncaa.org/sites/default/files/Recruiting Fact Sheet WEB.pdf.

Pascarella, E. T., Pierson, C. T., Wolniak, G. C., \& Terenzini, P. T. (2004). First generation college students: Additional evidence on college experience and outcomes. Journal of Higher Education, 75, 249-284

Paunio, T., Korhonen, T., Hublin, C., Partinen, M., Kivimaki, M., Koskenvuo, M., \& Kaprio, J. (2008). Longitudinal Study on Poor Sleep and Life Dissatisfaction in a Nationwide Cohort of Twins. American Journal of Epidemiology, 169(2), 206-213. doi: 10.1093/aje/kwn305

Pavot, W., \& Diener, E. (1993). Review of the Satisfaction With Life Scale. Psychol Assess, 5, 164-172.

Pavot, W., \& Diener, E. (2008). The Satisfaction With Life Scale and the emerging construct of life satisfaction. J Posit Psychol, 3, 137-152.

Pilcher, J. J. (1998). Affective and Daily Event Predictors of Life Satisfaction in College Students. Social Indicators Research, 43(3), 291-306. Retrieved from https://ww.jstor.org/stable/27522313

Piper, A. T. (2015). Sleep Duration and Life Satisfaction. SSRN Electronic Journal. doi: $10.2139 /$ ssrn.2599565

Serbu, J. (1997). Effect of college athletic participation on later life satisfaction and job satisfaction. College Student Journal, 31(2), 261-272.

Smeyers@ncaa.org. (2016, June 16). The First in Their Family. Retrieved November 15, 2019, from http://www.ncaa.org/about/resources/research/first-their-family. 
Stambulova, N. (2000). Athlete's crisis: A developmental perspective. International Journal of Sport Psychology, 31, 584-601.

Taylor, J., \& Ogilvie, B.C. (1994). A conceptual model of adaptation to retirement among athletes. Journal of Applied Sport Psychology, 6, 1-20.

The Difference in the College Division Levels. (n.d.). Retrieved from https://www.ncsasports.org/recruiting/how-to-get-recruited/college-divisions.

Wang, Y. S., \& Henrich, T. (2007). Relationships between the perception of coaching leadership behaviors and satisfaction among Taiwanese collegiate tae kwon do competitors. Journal of ICHPER-SD, 43(1), 16-20.

Weinstein, L., \&Laverghetta, A. (2009). College student stress and satisfaction with life. College Student Journal 43(4), 1161-62.

World Health Organization. The first ten years the World Health Organization. Geneva: World Health Organization, 1958. 


\section{Appendix A}

$\underline{\text { Satisfaction with Life Scale }}$

Below are five statements with which you may agree or disagree. Using the 1-7 scale below, indicate your agreement with each item by indicating the appropriate number on the line below that statement. Please be open and honest with your responding. The 7point scale is as follows: $1=$ strongly disagree, 2 = disagree, $3=$ slightly disagree, $4=$ neither agree nor disagree, $5=$ slightly agree, $6=$ agree, $7=$ strongly agree (Diener et al., 1985)

1. In most ways my life is close to my ideal.

$\begin{array}{lllllll}1 & 2 & 3 & 4 & 5 & 6 & 7\end{array}$

2. The conditions of my life are excellent.

$\begin{array}{llllllll}1 & 2 & 3 & 4 & 5 & 6 & 7\end{array}$

3. I am satisfied with my life.

$\begin{array}{lllllll}1 & 2 & 3 & 4 & 5 & 6 & 7\end{array}$

4. So far I have gotten the important things I want in life

$\begin{array}{lllllll}1 & 2 & 3 & 4 & 5 & 6 & 7\end{array}$

5. If I could live my life over, I would change almost nothing

$\begin{array}{lllllll}1 & 2 & 3 & 4 & 5 & 6 & 7\end{array}$


Appendix B

Athletic history and current sports demands

1. Do you consent to continue this Survey

Yes No

2. Where do you currently/most recently play football

Linfield College Portland State University

3. Year of eligibility:

4. Year(s) at current institution:

5. At what level did you start your college career (DI, DIII, Junior College etc.)?

6. How many colleges/universities have you played for? (Please circle one)

$1 \quad 3+$

7. What is the highest division for which you've played? (please circle one)
DIII
DII
DIAA
DI

8. On average, how many hours per week are devoted to athletics? (i.e. practice, competition, meetings, workouts, team events, etc)

-During season__ hrs/week

-Off-season__ hrs/week

9. How much control do you feel you have over your current life?

(Please circle the option that best describes your situation)

I am in full control

I am mostly in control

I have some control

I have little control

I have no control

10. How many hours per week do you spend on activities not related to school or athletics (free time)? (please circle one)
$0-7$
8-14
$15-21$
$22+$

11. On average, how many hours of sleep do you get each night? (please circle one)
$0-4$
5-6
$7-8$
$9+$

12. At what age did you start playing organized sports? (please circle one)
$0-10$
11-13
14-16
$16+$ 
13. How many competitive/organized sports did you play in high school? (please circle one)

$0-1$ $2-3 \quad 3+$

14. At what age did you specialize in football? (please circle one)

Younger than $10 \quad 11-14 \quad 15-16 \quad 16-17$

$18+$

15. How does your level of satisfaction with your athletic experience now compare to when you were younger (high school/middle school)? (please circle one)

I am most satisfied with my current athletic experience

I was more satisfied with my athletic experience when I was younger

I am equally satisfied now as I was when I was younger 


\section{Appendix C}

\section{Letter of informed consent}

You are being asked to participate in a research study on the Life Satisfaction in Division I AA and Division III Collegiate Football Players. This study is being done by Krista Francisco, who is the Principal Investigator, from the School of Community Health at Portland State University in Portland, Oregon.

You are being asked to participate because you are either a Division I AA or Division III collegiate football player.

Agreeing to participation in this study involves agreeing to the following; completing a surbey via the Survey Monkey website regarding your athletic history and to assessing your life satisfaction. Completion of this questionnaire should take approximately 6 minutes.

There are risks of stress, emotional distress, inconvenience and possible loss of privacy associated with participation in this study. You may experience some discomfort while reading and/or answering questions included in these surveys. However, these risks are unlikely and not anticipated by the Principal Investigator. If you have questions or concerns pertaining to the risks of this survey, contact the investigator Krista Francisco.

The purpose of this study is to assess the life satisfaction and corresponding athletic demands of multiple levels of collegiate football. Levels of life satisfaction is a contributor to both physical and mental health. Assessing the levels of experienced life satisfaction and the athletic demands corresponding with said levels can help us to detect problems and direct in working towards a solution. Data collected through this survey will only be used for research project purposes and not released to outside sources. Data will be stored digitally on a password protected computer, as well on a password protected Survey Monkey account. All data transmitted from the site to the computer will be encrypted. Names will not be asked or connected to your questionnaire. All answers will be anonymous. Every measure will be taken to ensure your privacy and the security of your contribution, however we cannot guarantee confidentiality of all study data.

Information provided by you as part of this study is used by the study staff and, in some cases, may be shared with the sponsor of the study. There may be cases in which the Portland State University Institutional Review Board (IRB) that oversees human subject research, and/or other entities may be permitted access to these data records. Information will also be shared when required by law. In the case of child abuse, child neglect, elder abuse, harm to self or others, and/or any life threatening situations, the investigator is legally obligated to contact and report to the authorities. In these cases your confidentiality cannot be maintained. 
The investigator will not be privy to your name, or any other identifying information connected to your data, and therefor will not be published in relation to this study. You are under no obligation to participate in this study, nor continue your participation to completion. Your participation is completely voluntary and can be ceased at any time during this study should you decide the risks outweigh benefit. There is penalty of any kind for not participating in, or nor completing this study. There will be no compensation for participating in this research study.

If you have any questions, concerns or complaints regarding this study please contact Krista Francisco via email at kfranci2@pdx.edu or by phone at (509) 952-0896. You may also contact her associates at bwipfli@pdx.edu.

Any questions regarding your rights as a research participant can be directed to the PSU Office for Research Integrity (ORI) at (503) 725-2227 or 1(877) 480-4400. The ORI is the office that supports the PSU Institutional Review Board (IRB). The IRB is a group made up of both PSU and community members, whose purpose is to provide independent oversite of safety and ethical issues related to research involving human

participants. Further information can be accessed through the IRB website at https://sites.google.com/a/pdx.edu/research/integrity.,

\section{Consent}

By providing (or not providing) consent you are making a decision about whether or not you chose to participate in this study. Clicking yes at the bottom of this page indicated you have read and understand the information provided. You have had the opportunity to ask questions, and your questions have been answered to your satisfaction. By clicking yes you agree to participate in this study. You may print out a copy of this consent form for your records.

Thank you for your time,

Krista Francisco 
Appendix D

Human Subjects Approval

September 11, 2019

\section{Notice of Exempt Certification}

Dear Investigator,

The PSU Human Research Protection Program (HRPP) reviewed the following submission:

Investigators Brad Wipfli and Krista Francisco HRPP \# 196602-18 Title Life Satisfaction in Division I AA and Division III Collegiate Football 2019 Funding Agency / Kuali \# N/A

Determination Date September 11, 2019 Expiration Date N/A Review Category(ies) Exempt:

\#2

Research Integrity determined this study qualifies as exempt and is satisfied the provisions for protecting the rights and welfare of all subjects participating in research are adequate. The study may now proceed in accordance with the plans submitted (HRPP Forms enclosed). Please note the following ongoing Human Research Protection Program (HRPP) requirements:

Changes to Study Activities: Any changes to the study must be submitted to Research Integrity for review and determination prior to implementation.

Unanticipated Problems or Adverse Events: Notify Research Integrity within 5 days of any unanticipated problems or adverse events that occur as a result of the study.

Study Completion: Notify Research Integrity when the study is complete; Research Integrity will request annual updates on the study status. Study materials must be kept for at least three years following completion.

Compliance: The PSU IRB (FWA00000091; IRB00000903) and Research Integrity comply with 45 CFR Part 46, 21 CFR Parts 50 and 56, and other federal and Oregon laws and regulations, as applicable.

If there are any questions, please contact the ORI at psuirb@pdx.edu or call 503-725-5484.

Sincerely,

Comedy Millar, HRPP Administrator Research Integrity

PSU HRPP Form 1: 03/01/2019 Page 1 